\title{
Pengaruh Penerapan Strategi Segmenting, Targeting, Dan Positioning Terhadap Pembiayaan Mikro Pada PT. BRI Syariah KCP Muara Bungo
}

\author{
Feby Yulia Ningsih 1 \\ Institut Agama Islam (IAI) Yasni Bungo \\ Email :feby@gmail.com
}

\begin{abstract}
Abtrak
Fokus penelitian mengkaji tentang pengaruh penerapan strategi segmenting, targeting, dan positioning terhadap pembiayaan mikro pada Pt. Bri Syariah Kcp Muara Bungo. Metode penelitian yang digunakan bersifat kuantitatif dan membatasi permasalahan yang ada pada rumusan masalah. Rumusan masalah dinyatakan dalam kalimat pernyataan, selanjutnya peneliti menggunakan teori untuk menjawabnya. Berdasarkan hasil penelitian Pengaruh Penerapan Strategi Segmenting, Targeting, dan Positioning Terhadap Pembiayaan Mikro pada PT. BRI Syariah KCP Muara. Bungo Berdasarkan uji parsial terlihat bahwa ada dua variabel yang tidak berpengaruh, yaitu segmenting dan targeting, Sedangkan variabel positioning berpengaruh positif terhadap pembiayaan mikro pada PT. BRI Syariah KCP Muara Bungo. uji secara simultan, ketiga variabel yaitu segmenting, targeting dan positioning secara bersama-sama berpengaruh positif terhadap pembiayaan mikro pada PT. BRI Syariah KCP Muara Bungo.
\end{abstract}

Kata Kunci: Strategi Segmenting, Targeting, Positioning, Pembiayaan Mikro

\begin{abstract}
Abstrak
The research focus examines the effect of the application of segmenting, targeting, and positioning strategies on micro-financing at Pt. Bri Syariah Kcp Muara Bungo. The research method used is quantitative and limits the problems that exist in the problem formulation. The formulation of the problem is stated in a statement sentence, then the researcher uses the theory to answer it. Based on the research results of the Effect of the Application of Segmenting, Targeting and Positioning Strategies on Microfinance at PT. BRI Syariah KCP Muara. Bungo Based on the partial test, it shows that there are two variables that have no effect, namely segmenting and targeting, while the positioning variable has a positive effect on micro-financing at PT. BRI Syariah KCP Muara Bungo. Simultaneously test, the three variables, namely segmenting, targeting and positioning together have a positive effect on micro financing at PT. BRI Syariah KCP Muara Bungo.
\end{abstract}

Keywords: Segmenting Strategy, Targeting, Positioning, Micro Financing

\section{A. Pendahuluan}

Istilah Perbankan Islam merupakan fenomena baru dalam ekonomi modern, kemunculannya seiring dengan upaya gencar yang dilakukan oleh pakar Islam dalam mendukung ekonomi Islam yang diyakini akan mampu mengganti dan memperbaiki sistem ekonomi konvensional yang berbasis pada bunga. Karena itulah sistem 
Feby Yulia Ningsih: Pengaruh Penerapan Strategi...

perbankan Islam menerapkan sistem bebas bunga (interest free) dalam operasionalnya, dan karena itu rumusan yang paling lazim untuk mendefinisikan perbankan Islam adalah bank yang beroperasi sesuai dengan prinsip-prinsip syariat Islam, dengan mengacu kepada Alquran dan Sunnah sebagai landasan dasar hukum dan operasional2.

Marketing memiliki peranan penting pada sistem perbankan terutama dalam melakukan promosi kepada masyarakat, sehingga masyarakat mengetahui apa saja produk yang terdapat pada sebuah bank, pembiayaan merupakan produk jasa yang dimiliki oleh perbankan dan dijalankan oleh bagian pemasaran/marketing. Di dalam melakukan manajemen pemasaran setiap marketing harus menguasai bagaimana strategi pemasaran, hal ini digunakan untuk memposisikan suatu produk dalam benak konsumen sedemikian rupa sehingga produk tersebut memiliki keunggulan kompetitif yang berkesinambungan. Ada tiga elemen dalam strategi pemasaran yaitu segmenting, targeting dan positioning.

PT. Bank Rakyat Indonesia Syariah (BRIS) Kantor Cabang Pembantu (KCP) Muara Bungo merupakan salah satu lembaga keuangan syariah yang terdapat dikabupaten Bungo yang saat ini juga melakukan penyaluran pembiayaan pada segmen mikro. Dapat dilihat dari tabel dan diagram perkembangan dari pembiayaan mikro pada PT. BRI Syariah KCP Muara Bungo sebagai berikut :

Jumlah Pembiayaan dan Jumlah Nasabah Pembiayaan Mikro Pada PT. BRI Syariah KCP Muara Bungo

\begin{tabular}{|l|l|l|l|}
\hline No & Tahun & $\begin{array}{l}\text { Jumlah } \\
\text { Pembiayaan }\end{array}$ & Jumlah Nasabah \\
\hline 1 & 2017 & Rp. 18.000 .000 & 470 \\
\hline 2 & 2018 & Rp. 20.000 .000 & 478 \\
\hline 3 & 2019 & Rp. 8.000 .000 & 245 \\
\hline
\end{tabular}

${ }^{2}$ Sultan Remy Sjahdeini, Perbankan Islam, (Jakarta : PT Pustaka Utama Grafiti,2007) Cet . 3. h.1. 


\section{Jumlah Pembiayaan Mikro PT. BRI Syariah KCP \\ Muara Bungo}

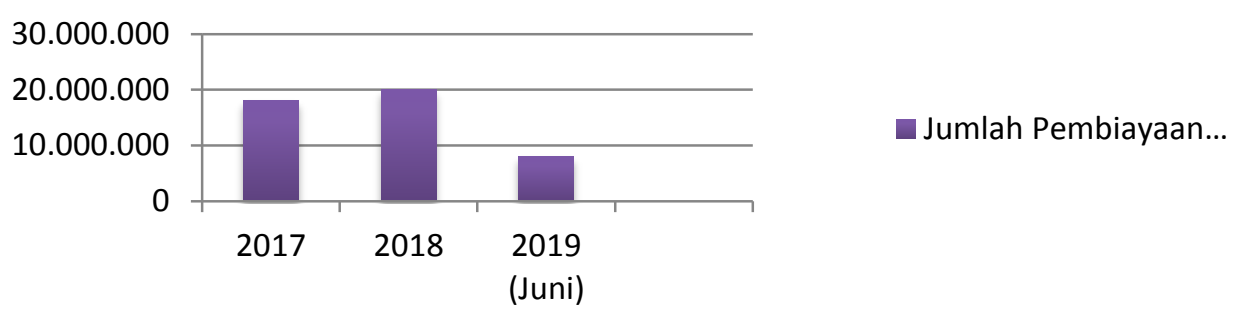

\section{Jumlah Nasabah Mikro Pada PT. BRI Syariah KCP Muara Bungo}

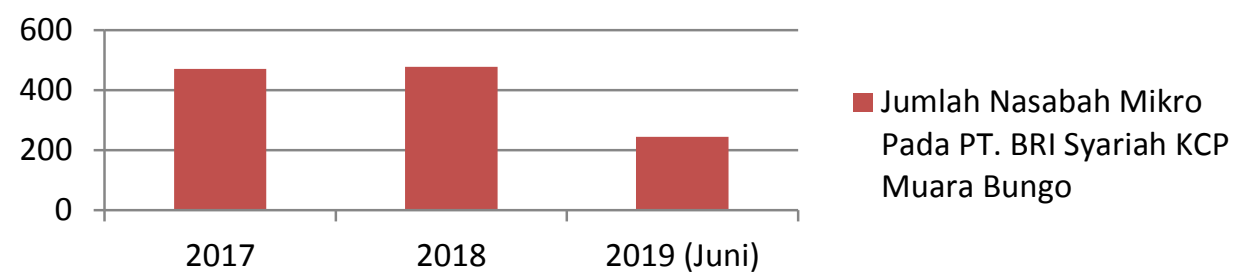

Dari tabel dan digram diatas dapat di simpulkan bahwa pada tahun 2017 besarnya pembiayaan mikro yang disalurkan oleh Bank Rakyat Indonesia Syariah (BRIS) KCP Muara Bungo adalah sebesar Rp. 18.000.000.000 dengan jumlah nasabah mikro sebanyak 470 orang. Pada tahun 2018 pembiayaan mikro di PT. Bank Rakyat Indonesia Syariah (BRIS) KCP Muara Bungo meningkat sebesar Rp. 20.000.000.000 dengan jumlah nasabah sebanyak 478 orang. Sedangkan pada tahun 2019 PT. Bank rakyat Indonesia Syariah (BRIS) KCP Muara Bungo baru menyalurkan pembiayaan mikro sebanyak Rp. 8.000.000.000 dengan jumlah nasabah sebanyak 245 orang.

Adanya perubahan jumlah nilai dan banyaknya nasabah penerima pembiayaan mikro di BRI Syariah KCP Muara Bungo tentunya tidak terlepas dari adanya penerapan strategi pemasaran segmenting, targeting, dan positioning. Hal ini telah dibuktikan dengan dilakukannya penelitian oleh Takdir pada tahun 2017 dengan judul "Pengaruh Strategi STP dan Personal Selling Terhadap Peningkatan Penjualan Pada PT. Bumi Sarana Utama di Makasar" di mana berdasarkan hasil pengujian secara parsial (Uji t) dengan hasil variabel straegi STP menunjukkan nilai $t$ hitung lebih besar dari $t$ tabel $(2,438>2,024)$, atau signifikan, $<\alpha \quad(0.002<0.05)$, berarti variabel strategi STP berpengaruh terhadap peningkatan penjualan pada PT. Bumi Sarana Utama.

Menurut penelitian yang dilakukan oleh Sri Ramlah dengan judul "Implementasi Segmenting, Targeting, Positioning Produk Tabungan Faedah IB (Fasilitas Serba Mudah IB) Pada PT. Bank BRISyariah KCP Pasuruan" teknik pengumpulan data melalui 
Feby Yulia Ningsih: Pengaruh Penerapan Strategi...

obsevasi langsung, wawancara dan dokumentasi. Hasil penelitian menunjukan bahwa implementasi strategi segmenting yang dilakukan yaitu segmen produk tabungan faedah mengena secara global, sedangkan implementasi strategi targeting pada produk tabungan faedah adalah ibu rumah tangga, masyarakat menengah kebawah. Kemudian untuk strategi implementasi positioning untuk tabungan faedah adalah memberi kemudahan dan pelayanan dengan "The Better and Different One".

Berdasarkan penjelasan di atas, dapat diketahui bahwa strategi segmenting, targeting, dan positioning penting untuk diterapkan guna untuk meningkatkan pencapaian target perusahaan maupun target pribadi marketing dalam membangun nilai lebih atas produk yang ditawarkan di benak konsumen.

\section{B. Landasan Teori}

\section{Pengertian Pembiayaan Mikro syariah}

Pembiayaan mikro syariah merupakan salah satu tugas BMT, yaitu pemberian fasilitas penyediaan dana untuk memenuhi kebutuhan pihak-pihak yang merupakan defisit unit.Calon anggota sebagai pelaku usaha yang tidak bertentangan dengan syariah, juga tidak termasuk jenis penyaluran dana yang dilarang secara hukum.Pembiayaan menurut sifat penggunaannya dapat dibagi menjadi dua hal yaitu :

a Pembiayaan usaha kecil (pembiayaan mikro syariah), yaitu pembiayaan yang diberikan kepada para anggota yang berprofesi sebagai pedagang atau pengusaha kecil, baik untuk mengembangkan peputaran usaha maupun penyediaan prasarana dan sarana usaha.

b. Pembiayaan konsumtif, yaitu pembiayaan yang diberikan kepada anggota untuk kebutuhan konsumtif, seperti pembelian barang elektronik, kendaraan dan rumah. ${ }^{3}$

\section{Definisi Strategi Pemasaran}

Strategi pemasaran adalah memilih dan menganalisis pasar sasaran yang merupakan suatu kelompok orang yang ingin dicapai oleh satu perusahaan dan menciptakan suatu bauran pemasaran yang cocok dan yang dapat memuaskan pasar sasaran tersebut. 4

\footnotetext{
${ }^{3}$ Purwanti, "Pengaruh Pembiayaan Mikro Syariah Jam Kerja dan Lokasi Usaha Terhadap Pendapatan Usaha Kecil dan Mikro (UKM) Studi Kasus Pada Anggota Pelaku UKM di BMT Surya Madani Boyolali Tahun 2016" Skripsi, Jurusan Perbankan Syariah IAIN Surakarta, 2017), h. 17-18.

${ }^{4}$ Ibid., h.278.
} 
FEBY YULIA NINGSIH: Pengaruh Penerapan Strategi...

Strategi pemasaran dapat direncanakan sdemikian rupa sehingga dapat berhasil sebagaimana yang diharapkan. Langkah-langkah perencanaan strategi pemasaran adalah $:^{5}$

a. Teliti situasi marketing saat ini. Situasi pemasaran saat ini sangat dipengaruhi oleh pengalaman masa lalu, tingkat persaingan, serta analisis kekuatan dan kelemahan.

b. Analisis lingkungan eksternal. Lingkungan eksternal yang memengaruhi bisnis adalah kondisi ekonomi makro, tingkat bunga, inflasi, pengangguran, dan pendapatan perkapita, berkurangnya pasokan bahan baku, keadaan musim, banjir dan hujan.

c. Analisis peluang dan arahan untuk mencapai peluang. Bisnis yang sukses adalah yang selalu memperhatikan peluang yang ada.

d. Desain strategi pemasaran. Strategi pemasaran ini dapat dikembangkan dengan mempertimbangkan segmentasi pasar, target bisnis pasa, positioning produk (apa yang istimewa dan spesifik dari produk), dan bauran pemasaran yang akan digunakan.

Menurut hermawan Kartajaya dan Philip Kotler, pemasaran memiliki elemen penting yang terdiri atas Strategy, Tactic, dan Value. Strategi meliputi segmentasi (Segmentation), penentuan target (Targeting) dan memosisikan diri (Positioning). ${ }^{6}$

\section{1) Segmentation (Segmentasi)}

Segmenting (segmentasi pasar) menurut kotler adalah pasar yang terdiri dari sekelompok pelanggan yang memiliki sekumpulan kebutuhan dan keinginan yang serupa. Sedangkan menurut Kasali segmentasi merupakan proses mengkotakkotakkan pasar (yang heterogen) ke dalam kelompok-kelompok yang memiliki kesamaan kebutuhan dan kesamaan karakter yang memiliki respon yang sama dalam membelanjakan uangnya. Karena sifatnya homogen, maka akan sulit bagi produsen untuk melayaninya, oleh karena itu pemasar harus memilih segmensegmen tertentu saja dan meninggalkan bagian pasarlainnya.7 Segmentasi pasar

\footnotetext{
5Ibid., 280.

${ }^{6}$ Sentot Imam Wahjono. Manajemen Pemasaran Bank (Yogyakarta: Graha Ilmu,2010). h. 71.

${ }^{7}$ Sri Ramlah, "Implementasi Segmenting, Targeting, dan Positioning Produk Tabungan Faedah. IB (Fasilitas Serba Mudah IB) Pada PT. Bank BRISyariah KCP Pasuruan” (Skripsi, Sarjana Ekonomi UIN Maulana Malik Ibrahim Malang, 2017), h. 19-20.
} 
Feby Yulia Ningsih: Pengaruh Penerapan Strategi...

dapat dibedakan dengan menggunakan variabel-variabel segmentasi pasar, Kotler membagi segmentasi menjadi empat variabel utama yaitu :8

a) Segmentasi Geografis

Segmentasi geografis mengharuskan pembagian pasar menjadi unit-unit geografis yang berbeda seperti negara, wilayah, provinsi,kota atau lingkungan rumah tangga. Perusahaan dapat memutuskan untuk beroperasi dalam satu wilayah geografis atau beroperasi dalam seluruh wilayah tetapi memberikan perhatian pada variasi lokal.

b) Segmentasi Demografis

Segmentasi demografis merupakan dasar untuk membedakan kelompokkelompok pelanggan. Pasar dibedakan menjadi kelompok-kelompok berdasarkan variabel seperti usia, ukuran keluarga, siklus hidup keluarga, jenis kelamin, penghasilan, pekerjaan, pendidikan, agama, ras, generasi, kewarganegaraan, dan kelas sosial.

c) Segmentasi Psikografis

Pada segmentasi ini pasar dibagi ke dalam kelompok yang berbeda berdasarkan gaya hidup atau kepribadian akan nilai. Konsumen dalam kelompok yang sama dapat menunjukkan gambaran psikografis yang berbeda.

d) Segmentasi Menurut Perilaku

Dalam segmentasi ini pasar dibagi menjadi kelompok-kelompok berdasarkan pengetahuan, sikap, pemakaian, atau tanggapan mereka terhadap suatu produk. Untuk membentuk segmen pasar awal perlu adanya variabel perilaku kejadian, manfaat,status pemakai, tingkat pemakaian, status kesetian, tahap kesiapan pembeli, dan sikap.

Menurut Tjiptono, Kotler,dan Swastha yang dikuti oleh Dewy, agar proses segmentasi pasar dapat efektif dan bermanfaat bagi perusahaan, maka segmentasi pasar harus memenuhi kriteria dan syarat, sebagai berikut: ${ }^{9}$

1) Dapat diukur, baik besarnya maupun luasnya serta daya beli segmen pasar tersebut.

${ }^{8}$ Muhammaf Zulkarnain, "Strategi Pemasaran Segmenting, Targeting, dan Positioning Pada Produk Pembiyaan oleh Divisi Marketing BMT Taruna Sejahtera Kantor Cabang Suruh" (Skripsi, Jurusan Perbankan Syariah IAIN Maulana Salatiga, 2017), h. 17-18.

${ }^{9}$ Risa Windasari, "Strategi Pemasaran Produk Pembiayaan Mikro 25iB BRI Syariah KC Semarang” (Skripsi, Jurusan Perbankan Syariah UIN Walisongo Semarang, 2018), h. 12. 
FEBY YULIA NINGSIH: Pengaruh Penerapan Strategi...

2) Dapat dicapai atau dijangkau, sehingga dapat dilayani secara selektif.

3) Cukup luas, sehingga dapat menguntungkan jika dilayani.

4) Dapat dilaksanakan, sehingga semua program yang tekah disusun untuk menarik dan melayani segmen pasar itu dapat efektif.

5) Dapat dibedakan, segmen-segmen dapat dipisah-pisahkan secara konseptual dan memberikan tanggapan yang berbeda terhadap unsur-unsur dan program-program bauran pemsaran yang berlainan.

\section{2) Targeting (Penentuan Target)}

Menurut Kotler yang dikutip Rahmi mendefinisikan targeting sebagai berikut:argeting adalah memilih satu atau lebih segmen pasar yang akan dimasuki atau bagaimana cara perusahaan mengoptimalkan suatu pasar dan dalam penentuan target pasar perusahaan harus menggunakan konsep prioritas, varibilitas dan fleksibilitas.Sedangkan definisi targeting menurut Keegan \& Green yang dikutip oleh Joni Iskandar sebagai berikut:Targeting adalah proses pengevaluasian segmentasi dan pemfokusan strategi pemasaran pada suatu negara, propinsi, atau sekelompok orang yang memiliki potensi untuk memberikan respon.

Jadi berdasarkan pendapat para ahli diatas dapat disimpulkan targeting merupakan pemilihan segmen pasar yang telah difokuskan yang kemudian dipilih untuk dijadikan pasar sasaran dengan kriteria pasar homogen. Dengan demikian pasar yang akan dituju akan lebih spesifik dan memungkinkan produsen meraih konsumen lebih potensial, sehingga potensi respon pasar akan lebeih besar. ${ }^{10}$

Menurut Kasali yang dikutip oleh Dewy ada empat yang harus dipenuhi dalam mendapatkan pasar sasaran itu adalah sebagai berikut :11

a) Responsif

Pasar sasaran harus responsif terhadap produk atau produk pemasaran yang dikembangkan. Langkah ini dimulai dengan studi segmentasi yang jelas karena tanpa pasar sasaran yang jelas produsen menanggung resiko yang terlalu besar.

b) Potensi Penjualan

${ }^{10} \mathrm{Ibid}$

11Windasari, Perbankan Syariah, h. 13. 
Feby Yulia Ningsih: Pengaruh Penerapan Strategi...

Potensi penjualan harus cukup luas. Semakin besar pasar sasaran, semakin besar nilainya. Besarnya bukan hanya ditentukan oleh jumlah populasi tapi juga daya beli dan keinginan pasar untuk memiliki produk tersebut.

c) Pertumbuhan yang Memadai

Pasar yang tidak dengan segera bereaksi. Pasar tumbuh perlahan-lahan sampai akhirnya meluncur dengan cepat dan mencapai titik pendewasaan.

d) Jangkauan Media

Pasar sasaran dapat dicapai dengan optimal kalau pemasar tepat memilih media untuk mempromosikan dan memperkenalkan produknya.

\section{3) Positioning (Pemosisian Diri)}

Bentuk-bentuk strategi positioning Hal yang paling penting dalam proses STP (Segmenting, Targeting, Positioning) adalah mencoba menempatkan produk di benak konsumen dengan ciri-ciri yang untuk yang bisa dibedakan dengan produk lainnya atau disebut positioning.

Positioning merupakan cara pemasar menanamkan citra, persepsi dan imajinasi atas produk yang ditawarkan kepada konsumen melalui proses komunikasi. Positioning tidak sama dengan segmentasi baik difersinasi ataupun konsentrasi. Dengan perkataan lain, positioning bukan menempatkan produk untuk kelompok tertentum tetapi berusaha menanamkan citra produk di benak konsumen pada segmen yang telah dipilih. Positioning berhubungan bagaimana memainkan komunikasi agar dalam benak konsumen tertanam suatu citra tertentu.

Dengan kata lain positioning adalah suatu tindakan atau langkah-langkah yang dilakukan oleh perusahan dalam upaya penawaran nilai dimana dalam satu segmen tertentu konsumen mengerti dan menghargai apa yang dilakukan suatu perusahan dibandingkan dengan pesaingnya. Jadi positioning bukan menciptakan produk dengan menempatkan pada segmen tertentu, tapi positioning menempatkan produk di benak konsumen pada segmen tertentu dengan cara komunikasi. Komunikasi yang dibangun oleh pemasar harus menciptakan hubungan yang positif. 
FEBY YULIA NINGSIH: Pengaruh Penerapan Strategi...

Kotlermenjelaskan bahwa terdapat beberapa cara product positioning yang dapat dilakukan pemasar dalam memasarkan produk kepada konsumen yang dituju antara lain: ${ }^{12}$

a) Penetapan Posisi Menurut Atribut

Ini terjadi bila suatu perusahaan memposisikan dengan menonjolkan atribut produk yang lebih unggul dibandingkan pesaingnya, seperti ukuran, lama keberadaannya, dan seterusnya.

b) Penentuan Posisi Menurut Manfaat

Dalam pengertian ini produk diposisikan sebagai pemimpin dalam suatu manfaat tertentu.

c) Penentuan Posisi Menurut Penerapan dan Penggunaan.

Seperangkat nilai-nilai penggunaan atau penerapan inilah yang digunakan sebagai unsur yang ditonjolkan dibandingkan pesaingnya.

d) Penentuan Posisi Menurut Pemakai.

Memposisikan produk sebagai yang terbaik untuk sejumlah kelompok pemakai. Dengan kata lain pasar sasaran lebih ditujukan pada sebuah atau lebih komunitas, baik dalam arti sempit maupun dalam arti luas.

e) Penentuan Posisi Menurut Pesaing.

Klaim produk dihubungkan dengan posisi persaingan terhadap pesaing utama.

f) Penentuan Posisi Menurut Kategori Produk.

Produk diposisikan sebagai pemimpin dalam kategori produk tertentu.

g) Penentuan Posisi Menurut Harga.

Perusahaan berusaha menciptakan kesan/citra berkualitas tinggi lewat harga premium atau sebaliknya menekankan harga murah sebagai indikator nilai.

Pembiayaan mikro merupakan salah satu produk pembiayaan yang disalurkan oleh lembaga keuangan syariah guna meningkatkan kesejahteraan dan peningkatan kegiatan usaha masyarakat, sehingga setiap marketing harus menguasai strategi pemasaran guna mencapai target perusahaan maupun target pribadinya. Adapun

${ }^{12}$ Takdir, "Pengaruh Strategi STP dan Personal Selling Terhadap Peningkatan Penjualan Pada PT. Bumi Sarana Utama di Makasar" (Skiripsi, Sarjana Manajemen Ekonomi UIN Makasar, 2017), h. 36-37. 
Feby Yulia Ningsih: Pengaruh Penerapan Strategi...

strategi pemasaran yang biasanya digunakan dalam pembiayaan mikro adalah strategi pemasaran segmenting, targeting dan positioning.

Gambar 1

Kerangka Berpikir

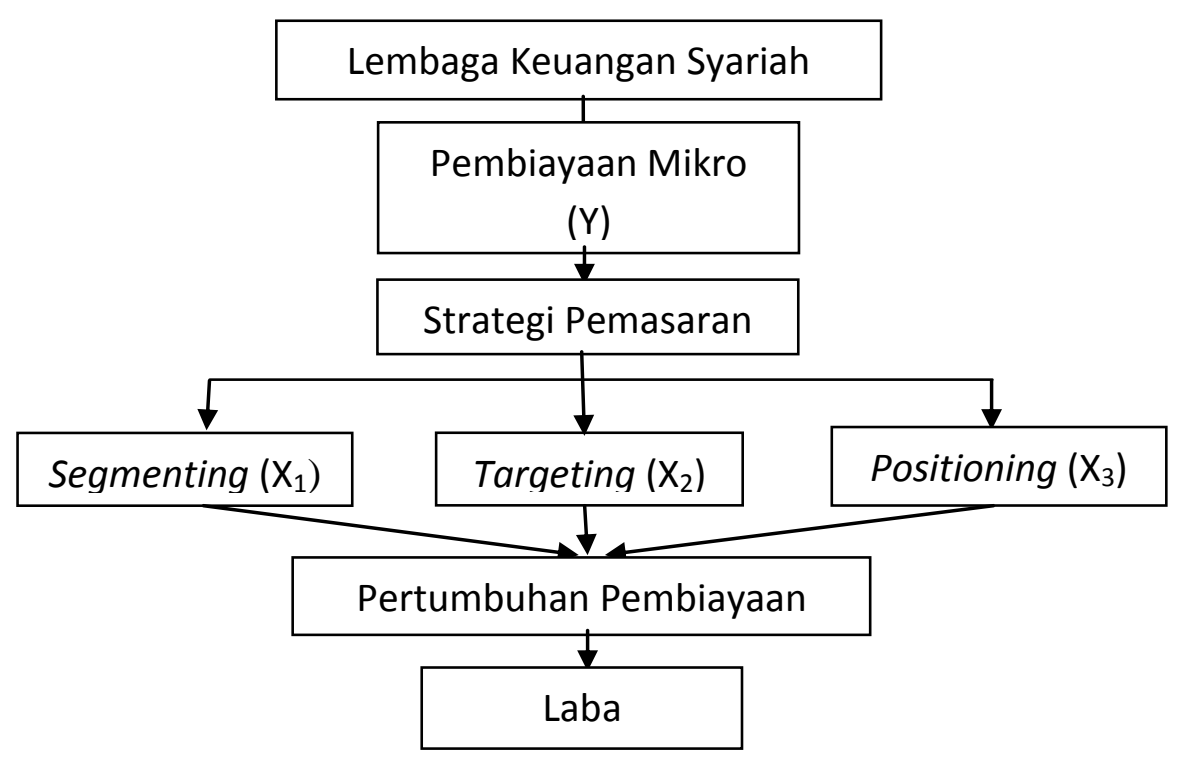

\section{Metode Penelitian}

Desain penelitian ini berawal dari masalah yang bersifat kuantitatif dan membatasi permasalahan yang ada pada rumusan masalah. Rumusan masalah dinyatakan dalam kalimat pernyataan, selanjutnya peneliti menggunakan teori untuk menjawabnya. Desain penelitian ini menghubungkan antara variabel X dan variabel Y. Penelitian ini terdiri dari tiga variabel, yaitu variabel bebas (X) yaitu segmenting, targeting, dan positioning dan variabel terkait (Y) yaitu pembiayaan mikro.

Populasi adalah semua nilai hasil perhitungan dan pengukuran, baik kuantitatif maupun kualitatif pada karakteristik tertentu mengenai sekelompok objek yang lengkap dan jelas. Dengan kata lain, populasi adalah keseluruhan subjek penelitian. ${ }^{13}$ Dalam hal ini peneliti mengambil penelitian yang berkaitan tentang pengaruh penerapan strategi segmenting, targeting, dan positioning terhadap pembiayaan mikro. Sehingga populasinya bergantung pada berapa jumlah konsumen pada tahun 2017, 2018, dan pada tahun 2019 (sampai bulan Juni sebanyak) 1.193 orang pada PT. BRI Syariah KCP Muara Bungo.Dari populasi diatas diambil penarikan sampel yang ditinjau dari banyaknya anggota populasi yaitu populasi terbatas

${ }^{13}$ Boedi Abdullah dan Beni Ahmad Saebani, Metode Penelitian Ekonomi Islam Muamalah (Bandung: CV Pustaka Setia, 2014), h. 34. 
FEBY YULIA NINGSIH: Pengaruh Penerapan Strategi...

(terhingga) dan ditinjau dari sudut sifatnya adalah populasi homogen.Metode yang digunakan peneliti dalam pengambilan sampel yaitu metode probability sampling yang merupakan teknik pengambilan sampel yang memberikan peluang yang sama bagi setiap unsur (anggota) populasi untuk dipilih menjadi anggota sampel. ${ }^{14}$ Di dalam penelitian ini menggunakan teknik sampling incidental.

Melihat pernyataan diatas maka pengambilan sampel menggunakan rumus dari Slovin untuk tingkat kesalahan 10\% yaitu :15 Karena Populasi berjumlah 1.193, dan tingkat kepercayaan 90\% maka dengan model slovin dapat ditentukan jumlah sampel pada penelitian ini sebanyak 92 nasabah.

Untuk menganalisis bagaimana pengaruh penerapan strategi segmenting, targeting, dan positioning terhadap pembiayaan mikro di PT. Bank Rakyat Indonesia Syariah (BRIS) KCP Muara Bungo, akan dianalisa dengan menggunakan metode statistik diskriptif, yaitu dengan pendekatan analisis regresi.

\section{Hasil Dan Pembahasan}

Dalam penelitian ini diketahui bahwa nilai koefisien determinasi (R2) sebesar 0,286 atau 28,6\%. Besarnya nilai koefisien determinasi tersebut menunjukkan bahwa variabel independen yang terdiri dari segementing $\left(\mathrm{X}_{1}\right)$, targeting $\left(\mathrm{X}_{2}\right)$ dan positioning $\left(\mathrm{X}_{3}\right)$ terhadap variabel dependen yaitu pembiayaan mikro (Y) sebesar 28,6\%, sedangkan sisanya sebesar $71,4 \%$ dijelaskan oleh variabel lain yang tidak dimasukkan dalam model penelitian ini.

Berdasarkanhasilsecara simultan inidiperoleh nilai $\mathrm{F}$ hitung sebesar 11,751 sedangkan besarnya nilai F tabel adalah sebesar 2,71. Karena nilai F hitung 11,751 > F tabel 2,71 maka hipotesis nol $\left(\mathrm{H}_{0}\right)$ ditolak, dengan demikian hipotesis satu $\left(\mathrm{H}_{1}\right)$ yang mengatakan strategi segmenting, targeting, dan positioning berpengaruh positif terhadap pembiaayaan mikro adalah benar atau terbukti. Berdasarkan hasil penelitian ini diuji secara parsial sebagai berikut :

\section{Pengaruh Segmentasi Terhadap Pembiayaan Mikro}

Dari hasil perhitungan diperoleh nilai t hitung sebesar 1,111, sedangkan $\mathrm{t}$ tabel pada taraf signifikansi $(\alpha)$ sebesar 0,05 dengan degree of freedom $(\mathrm{df})=92$ 3-1 = 88 yaitu sebesar 1,987. Karena nilai $\mathrm{t}$ hitung 1,111 < t tabel 1,987 maka

${ }^{14}$ Syofian Siregar, Statistik Parametrik untuk Penelitian Kuantitatif (Jakarta: PT Bumi Aksara, 2014), cet.4, h. 60 .

${ }^{15}$ Siregar, Statistik Parametrik untuk Penelitian Kuantitatif, h. 61. 
Feby Yulia Ningsih: Pengaruh Penerapan Strategi...

hipotesis nol $\left(\mathrm{H}_{0}\right)$ diterima dan hipotesis satu $\left(\mathrm{H}_{1}\right)$ ditolak. Hal ini berarti variabel segmenting tidak berpengaruh secara statistik terhadap pembiayaan mikro pada PT. BRI Syariah KCP Muara Bungo.

\section{Pengaruh Targeting Terhadap Pembiayaan Mikro}

Dari hasil perhitungan diperoleh nilai t hitung sebesar 1,117, sedangkan $t$ tabel pada taraf signifikansi $(\alpha)$ sebesar 0,05 dengan degree of freedom $(\mathrm{df})=92$ 3-1 = 88 yaitu sebesar 1,987. Karena nilai $\mathrm{t}$ hitung 1,117 < t tabel 1,987 maka hipotesis nol $\left(\mathrm{H}_{0}\right)$ diterima dan hipotesis satu $\left(\mathrm{H}_{1}\right)$ ditolak. Hal ini berarti variabel targeting tidak berpengaruh secara statistik terhadap pembiayaan mikro pada PT. BRI Syariah KCP Muara Bungo.

\section{Pengaruh Positioning Terhadap Pembiayaan Mikro}

Dari hasil perhitungan diperoleh nilai t hitung sebesar 3,527, sedangkan $\mathrm{t}$ tabel pada taraf signifikansi $(\alpha)$ sebesar 0,05 dengan degree of freedom $(\mathrm{df})=92$ 3-1 = 88 yaitu sebesar 1,987. Karena nilai t hitung 3,527 > t tabel 1,987 maka hipotesis nol $\left(\mathrm{H}_{0}\right)$ ditolak dan hipotesis satu $\left(\mathrm{H}_{1}\right)$ diterima. Hal ini berarti variabel positioning berpengaruh secara statistik terhadap pembiayaan mikro pada PT. BRI Syariah KCP Muara Bungo.

Dengan kata lain positioning adalah suatu tindakan atau langkah-langkah yang dilakukan oleh perusahan dalam upaya penawaran nilai dimana dalam satu segmen tertentu konsumen mengerti dan menghargai apa yang dilakukan suatu perusahan dibandingkan dengan pesaingnya. Jadi positioning bukan menciptakan produk dengan menempatkan pada segmen tertentu, tapi positioning menempatkan produk di benak konsumen pada segmen tertentu dengan cara komunikasi. Komunikasi yang dibangun oleh pemasar harus menciptakan hubungan yang positif.

\section{E. Kesimpulan}

Berdasarkan hasil penelitian dan pembahasan pada bab-bab yang telah dibahas sebelumnya, maka kesimpulan yang diperoleh dari penelitian Pengaruh Penerapan Strategi Segmenting, Targeting, dan Positioning Terhadap Pembiayaan Mikro pada PT. BRI Syariah KCP Muara Bungo adalah

Berdasarkan uji parsial terlihat bahwa ada dua variabel yang tidak berpengaruh, yaitu segmenting dan targeting tidak berpengaruh terhadap pembiayaan mikro pada PT. BRI Syariah KCP Muara Bungo, Sedangkan variabel positioning berpengaruh positif terhadap pembiayaan mikro pada PT. BRI Syariah KCP Muara Bungo, Berdasarkan uji 
secara simultan, ketiga variabel yaitu segmenting, targeting dan positioning secara bersama-sama berpengaruh positif terhadap pembiayaan mikro pada PT. BRI Syariah KCP Muara Bungo.

\section{Daftar Pustaka}

Abdullah, Boedi dan Saebani, Beni Ahmad. Metode Penelitian Ekonomi Islam Muamalah. Bandung: CV Pustaka Setia, 2014

Purwanti, "Pengaruh Pembiayaan Mikro Syariah Jam Kerja dan Lokasi Usaha Terhadap Pendapatan Usaha Kecil dan Mikro (UKM) Studi Kasus Pada Anggota Pelaku UKM di BMT Surya Madani Boyolali Tahun 2016" Skripsi, Jurusan Perbankan Syariah IAIN Surakarta, 2017

Ramlah, Sri. "Implementasi Segmenting, Targeting, dan Positioning Produk Tabungan Faedah. IB (Fasilitas Serba Mudah IB) Pada PT. Bank BRISyariah KCP Pasuruan" (Skripsi, Sarjana Ekonomi UIN Maulana Malik Ibrahim Malang, 2017)

Saebani, Beni Ahmad. Metode Penelitian Ekonomi Islam Muamalah

Siregar, Syofian. Statistik Parametrik untuk Penelitian Kuantitatif. Jakarta: PT Bumi Aksara, 2014

Sjahdeini, Sultan Remy. Perbankan Islam. Cet . 3. Jakarta : PT Pustaka Utama Grafiti,2007 Takdir. "Pengaruh Strategi STP dan Personal Selling Terhadap Peningkatan Penjualan Pada PT. Bumi Sarana Utama di Makasar" (Skiripsi, Sarjana Manajemen Ekonomi UIN Makasar, 2017)

Wahjono, Sentot Imam. Manajemen Pemasaran Bank. Yogyakarta: Graha Ilmu,2010

Windasari, Risa. "Strategi Pemasaran Produk Pembiayaan Mikro 25iB BRI Syariah KC Semarang" (Skripsi, Jurusan Perbankan Syariah UIN Walisongo Semarang, 2018) Windasari. Perbankan Syariah

Zulkarnain, Muhammaf. "Strategi Pemasaran Segmenting, Targeting, dan Positioning Pada Produk Pembiyaan oleh Divisi Marketing BMT Taruna Sejahtera Kantor Cabang Suruh" (Skripsi, Jurusan Perbankan Syariah IAIN Maulana Salatiga, 2017) 